\title{
Native Americans and Monetary Sanctions
}

\author{
ROBERT STEWART, BRIEANNA WATTERS, VERONICA HOROWITZ, \\ RYAN P. LARSON, BRIAN SARGENT, AND CHRISTOPHER UGGEN
}

Native Americans are disproportionately affected by the criminal legal system, yet comparative analyses of criminal legal outcomes and experiences among racial and ethnic groups rarely center the experiences of Native Americans. This multimethod study examines how monetary sanctions are affecting Native American populations in Minnesota. Drawing on administrative criminal court data and qualitative fieldwork, we find that Native Americans are subject to among the largest overall legal financial obligations (LFOs) in criminal court and carry the largest average LFO debt loads relative to other racial and ethnic groups in Minnesota, particularly when proximal to tribal lands. Moreover, monetary sanctions exacerbate existing poverty and spatial isolation in rural areas, compounding and further entrenching historical, systemic disadvantages that Native communities already face. We contextualize these findings within the broader history of U.S. settler colonialism, resource extraction, and dispossession.

Keywords: monetary sanctions, settler colonialism, rural criminal justice, Indigenous, extraction

The increased attention paid to monetary sanctions and their implications has produced a rich literature on racially and socioeconomically disparate effects of criminal financial pun- ishments. Unfortunately, much of this expanding literature has focused on the experiences and impacts of systems of monetary sanctions on people who are Black, Latinx, or White-

Robert Stewart is assistant professor of criminology and criminal justice at the University of Maryland, United States. Brieanna Watters is a doctoral candidate in the Department of Sociology at the University of Minnesota, United States. Veronica Horowitz is assistant professor of sociology at the University at Buffalo, SUNY, United States. Ryan P. Larson is a doctoral candidate in the Department of Sociology at the University of Minnesota, United States. Brian Sargent is assistant professor of public policy and sociology at the University of Massachusetts Amherst, United States. Christopher Uggen is Regents Professor and Martindale Chair in Sociology, Law, and Public Affairs at the University of Minnesota, United States.

(C) 2022 Russell Sage Foundation. Stewart, Robert, Brieanna Watters, Veronica Horowitz, Ryan P. Larson, Brian Sargent, and Christopher Uggen. 2022. "Native Americans and Monetary Sanctions." RSF: The Russell Sage Foundation Journal of the Social Sciences 8(2): 137-56. DOI: 10.7758/RSF.2022.8.2.07. This research was funded by a grant to the University of Washington from Arnold Ventures (Alexes Harris, PI). Partial support for this research came from a Eunice Kennedy Shriver National Institute of Child Health and Human Development research infrastructure grant, P2C HD042828, to the Center for Studies in Demography and Ecology at the University of Washington. We thank Chloe Hendrix, Naomi Cowan, and Sarah Peckman for their feedback and assistance. We also thank the faculty and graduate student collaborators of the Multi-State Study of Monetary Sanctions for their intellectual contributions to the project. Direct correspondence: Robert Stewart, at robstew@umd.edu, 2220 Samuel J. LeFrak Hall, College Park, MD 20742, United States.

Open Access Policy: RSF: The Russell Sage Foundation Journal of the Social Sciences is an open access journal. This article is published under a Creative Commons Attribution-NonCommercial-NoDerivs 3.0 Unported License. 
overlooking the stories of American Indians. ${ }^{1}$ The American Indian experience is also unique in that Native people have concurrent political affiliations as both members of their respective tribal nations and citizens of the United States (for the related but politically different case of monetary sanctions and undocumented immigrants, see Sanchez et al. 2022, this volume). Their experience is thus both racial and political: "unlike other disadvantaged groups, Native Americans' status as both tribal nationals and US citizens make them uniquely subject to interlocking forms of institutional power" (Ulmer and Bradley 2019, 339).

Here we draw on analyses of criminal court administrative data and in-depth interviews on how Native Americans fare within Minnesota's system of monetary sanctions. On several measures, Native Americans appear to experience much worse LFO outcomes relative to any other group. We find that a confluence of poverty, spatial isolation, and targeted enforcement produces increased debt levels among Native populations, further entrenching historical, enduring disparities and marginalization. Further, Native Americans in Minnesota carry the greatest overall burden from monetary sanctions. They are not only subject to considerable monetary sanctions, but also much more likely to have outsized LFO debt loads relative to other groups, especially in counties that overlap with tribal lands. The imposing financial strain exacerbates existing inequality and poverty, limiting mobility, and opportunities. The disproportionate burden of monetary sanctions that Native people in Minnesota experienced may be understood as part of much longer history of settler colonialism in which Native communities have become a key site for the social reproduction of race, criminal justice punishment, and settler colonialism.

\section{RESEARCH ON NATIVE AMERICANS}

\section{AND MONETARY SANCTIONS}

American Indians are often excluded in comparative analyses of incarceration rates among racial and ethnic groups. Issues of racial marginalization and disparity in the criminal jus- tice system related to Native peoples have been largely ignored. This omission pertains to discussions of the broader historical changes observed in American criminalization and punishment, as well as more critical work on criminal justice institutions, processes, and outcomes. By and large, U.S. criminal justice and sociolegal scholarship is neither systematically connected to nor informed by an understanding of Indigenous experiences. Only recently have social scientists acknowledged the importance of and need to consider the unique political status of American Indians in understanding their interactions with the criminal legal system (Beardall and Escobar 2016; Steinman 2012; Ulmer and Bradley 2019).

Although sparse, existing data illustrate the need for greater attention to issues around American Indian crime and criminal justice. American Indians are disproportionately overrepresented in arrests, convictions, and incarceration (see Carson 2020, appendix table 2). Data from the 2010 Census shows that American Indians are incarcerated at four times the rate of White Americans-38 percent higher than the national average. American Indian communities in states with larger Native populations often have considerably higher incarceration rates than other racial or ethnic groups. At the start of 2020 in Minnesota, for example, American Indians made up 8.7 percent of the prison population, almost eight times their proportion in the state's population (Minnesota Department of Corrections 2020). These disparities are even greater among Native women and youth. Native women are incarcerated at six times the rate of White women (Lakota People's Law Project 2015). Native youth are 30 percent more likely than White youth to be referred to juvenile court than to have charges dropped (Hartney 2008), and although they account for only 1 percent of all U.S. youth, they represent 70 percent of those committed to the Federal Bureau of Prisons, in part because of federal felony jurisdiction over reservations (Hartney and Vuong 2009). Native Americans are also more likely to be victims of serious violence than other groups. Victimiza-

1. Throughout this article, we use the terms American Indian, Native American, Native, and Indigenous. We explain our language choices in detail in Data and Methods. 
tion rates among Native Americans have traditionally been more than twice the national average. Recent research shows that 84 percent of Native women reported experiencing physical or sexual violence at some point in their livesperpetrators being overwhelmingly non-Native or nontribal members (Rosay 2016).

Despite the disproportionate criminal justice contact and rates of victimization among American Indians, and several calls for such research since at least the 1990s (Franklin 2013; Nielsen 2009; Pommersheim 1991; Young 1990; Ulmer and Bradley 2019), Native communities continue to be one of the least studied groups in the criminal justice context. Recent work by Jeffrey Ulmer and Mindy Bradley $(2018,2019)$ draws attention to the historically controversial and uniquely complex "jurisdictional maze" (Deloria and Lytle 1983) that characterizes contemporary Indian Country. Moreover, American Indians have strikingly similar criminal justice outcomes with the Indigenous peoples of Canada, Australia, New Zealand, and other former British colonies (Nielsen 2009)-underscoring that Native experiences continue to be shaped by the historical impact and contemporary processes of colonization and land dispossession.

\section{GEOGRAPHY, INEQUALITY, AND INDIGENEITY}

Monetary sanctions can vary widely geographically, and thus their impact can be highly context dependent (Martin et al. 2018). The literatures drawn on in this analysis illustrate that the historical processes of settler colonialismincluding land dispossession and geographic isolation, economic marginalization, and racialization-assimilation-may be understood as both evolving and ongoing with punishment, historically aimed at the tribal collective but having transformed to target the individual today.

\section{Legacies of Settler Colonialism}

Historically, the socioeconomic marginalization of Native people has been sustained through U.S. settler colonial law and criminal justice (Cunneen and Tauri 2019). However, until recently, social science scholarship has largely overlooked how settler colonial power has persistently dominated American Indians (Beardall and Escobar 2016; Steinman 2012). Like traditional colonialism, settler colonialism involves the domination of both geography and persons, perpetuated by racial ideologies of White supremacy and Indigenous inferiority (Steinmetz, Schaefer, and Henderson 2017). Unlike traditional colonialism, under which Indigenous populations are exploited and natural resources are exported, settler colonialism is a distinct social formation that aims to obtain Native land and control resources for permanent settlement and to establish a new society (Wolfe 1999; Veracini 2010; Glenn 2015; Steinman 2016).

Through the settler colonial project, new communities are created in foreign lands as settlers and settler power structures actively suppress Indigenous nations. Moreover, settler normativity is foundational; processes of settlement institutionalize settler privileges materially and discursively, constructing settlers and their culture as superior and modern and Indigenous nations and their cultures as inferior and primitive ... separation between settlers and Indigenous groups is rigidly enforced (Steinman 2016).

As Patrick Wolfe (1999) observes, "settler colonialism is a structure, not an event." Both government-authorized and settler-vigilante campaigns of violence were carried out against American Indians under U.S. settler colonialism regularly between the seventeenth and nineteenth centuries (Glenn 2015). Other modes of domination have included military liquidation, forced removal, assimilation, and Indigenous criminalization or institutionalization (Veracini 2010).

Under settler colonialism, land conflicts between Indian tribes and the U.S. government have been resolved several ways, including coercive treaties, forced removal, the reservation system, and allotment (Wilkins and Lomawaima 2001). Between 1830 and 1920, as Native nations and their treaty rights were seen as preventing Americanization and further land acquisition, Indian policy turned to intensive assimilation measures that included the reservation system, the formal end of treatymaking, and the incorporation of Indian lands into the United States, the extension of U.S. law 
over tribes (such as passage of the Major Crimes Act in 1885), the forced removal of Native children and the creation of boarding schools, and the institutionalization of Native racial understanding through blood-quantum laws. Such policies continue to have devastating impacts on Native communities in that "the traumas of being forced onto reservations and into board schools have affected tribes in differential ways, depending upon their location and perceived levels of assimilation" (Akee et al. 2017, 1940).

Yet although Native communities inherit the traumas of settler colonialism and the significant social problems they have caused, the allotment-era fractionation of Native lands (1887-1934) has also been significant for understanding the larger strategic evolution from collective to individual targeting of Native people. The General Allotment Act of 1887 was meant to create "independent" property-owning individuals out of Native people by converting $\mathrm{Na}$ tive American lands into individually owned property, distributing 80 - to 160 -acre lots to individual Indian "heads of household" (LaVelle 1999). This policy was carried out over and against the collective and heterogeneous forms of land ownership that were practiced by tribal nations, but it also furthered Native land loss through both direct sale and the appropriation of "surplus" land by the federal government. Indeed, President Theodore Roosevelt famously described allotment in his 1901 State of the Union as "a mighty pulverizing engine to break up the tribal mass" (American Presidency Project 2021). Allotment had immediate and long-term consequences on Native land holdings, but the policy further sought to denationalize tribes, dismantle tribal collectiveness, and minoritize American Indians (Chang 2011).

In addition to individuation, settler colonial relations and forms of domination are structured and reproduced through forms of debt, and these relations ensure conditions of structural inequality (Park 2018; Byrd et al. 2018; Kim 2018; Martin 2018; Murphy 2018). For example, although land conflicts between Indian tribes and the U.S. government have been understood as revolving around the political negotiation of treaties, land cession was often made easier for the federal government by encouraging tribal nations to incur enormous debts during the trade economy (Martin 2018; Murphy 2018). In doing so, Indian nations often believed that land cession was their only option for debt repayment.

Financial debt has been used not only proactively (by treaty) against American Indians, but also reactively (as punishment). From 1796 to 1920, the federal government's Indian Depredation Act allowed compensating European settlers for crimes committed by Indians on any lands "inhabited by citizens of the United States" (Park 2018, 57). If tribal nations could not pay the claims submitted by settlers, the U.S. government paid the damages out of tribal annuities. Land treaties were often accompanied by the assurance of annuities, which tribes relied on in exchange for the promise to cease hunting on their ancestral lands and to move to reservations. Although the federal government protected some level of tribal immunity by requiring settlers to formally accuse a tribe, the government nonetheless also denied this sovereign immunity, holding tribes responsible for the crimes of individuals and punishing them by giving their annuities to settlers.

Over time, federal, state, and local governments have continuously attempted to subjugate tribal nations by adopting different techniques to achieve this end (Corntassel and Witmer 2008). As American Indian communities have endured the evolving dialectic between their traditions and cultural values based in collectivity, and the imposition of settler colonial political values and legal systems, we see another progression: from the collective imposition of debt to more individualized extraction. In other words, the modes of settler colonial domination that once actively aimed to coerce Indian nations off their lands, onto reservations, and through assimilation-systematically producing enduring structural inequalities-may be understood today as targeted at the individual level through legal financial obligations.

\section{Rurality, LFOs, and Reservations}

Rurality has generally been taken for granted in our understanding of divergent experiences within the criminal justice system. The lack of research on rural criminal justice underscores and perpetuates the invisibility of rural com- 
munities of color and the unique inequalities that they experience (Eason 2017; Gottschalk 2020; Pruitt et al. 2018). For example, although rural places generally experience low crime rates, rural sociologists have pointed out that "American Indians and their communities are an anomaly, by suffering from unusually high rates of criminal victimization despite being predominantly rural" (Wells and Falcone 2008, 199). Other research has generally found a positive relationship between rurality and the severity of criminal legal punishments, including monetary sanctions (Olson and Ramker 2001; Ruback and Clark 2011). Kate O'Neill, Tyler Smith, and Ian Kennedy (2022, this volume), for example, find that rurality is associated with a significant increase in rates of women's imprisonment, with especially large increases in Indian Country. Such insight points to the need for greater visibility around the experiences of people of color-and Indigenous people in particular-in rural areas.

Some of the most misunderstood rural areas include American Indian reservations and the counties that surround them, in part because of variations in how rural is defined. Antiquated U.S. Census definitions, including defining rural as places with fewer than 2,500 residents and relying on narrow definitions of tribal lands, have led to a distorted perception of the significance of rurality to Native communities, compounding their marginalization (Dewees and Marks 2017; Fink 2020). Under this definition, more than 78 percent of American Indians outside of American Indian and Alaska Native areas-a commonly cited statistic for American Indian populations (Cunneen and Tauri 2019; Norris et al. 2012)-leading to the mistaken assumption that most American Indians do not live on or near tribal lands. But an alternative approach that more appropriately reflects the experiences of Native communities by centering reservations or trust lands and their surrounding counties in fact finds the opposite. The U.S. Department of Housing and Urban Development (HUD) took this approach in its 2014 report on socioeconomic and housing conditions of American Indians and Alaska Natives (Pettit et al. 2014). According to HUD's analysis, 42 percent of people who identified as nonHispanic American Indian or Alaska Native alone in the 2010 Census lived in tribal areas and 26 percent lived in surrounding counties, a total of 68 percent living on or near tribal homelands in what HUD termed American Indian and Alaska Native Counties. Thus, as findings suggest (O'Neill, Smith, and Kennedy 2022, this volume), it is likely that American Indian communities will bear the brunt of higher LFOs and other sanctions that are more characteristic of rural criminal legal systems.

\section{EXPECTATIONS REGARDING MONETARY}

\section{SANCTIONS, RACE, AND INDIGENEITY}

Based on classic and emerging research (Harris 2016; Harris, Evans, and Beckett 2011; Bing, Pettit, and Slavinski 2022, this volume; O'Neill, Smith, and Kennedy 2022, this volume), we anticipate the assessment of monetary sanctions to differ significantly by race, ethnicity, and indigeneity. Based on our reading of the settler colonialism literature, we anticipate that Native Americans will face heavy monetary sanctions, particularly when they are sentenced in close proximity to tribal lands. Consistent with research on rurality and criminal justice, greater financial penalties will likely contribute to existing poverty and spatial isolation. As Lindsay Bing, Becky Pettit, and Ilya Slavinski (2022, this volume) find in their analysis of Texas LFOs, we further expect to find that although monetary sanctions may be putatively race neutral in their application, they are not race neutral in their impacts. We expect that Native American communities and other communities of color will in particular will be burdened with significant LFO debt loads. In sum, we expect the amount and nature of monetary sanctions to be closely bound up with both indigeneity and geography and for these sanctions to compound Native marginalization.

With a goal of advancing research on monetary sanctions beyond extant work on race and punishment, we therefore ask three basic questions: How do such fines and fees rates compare for Native Americans and other groups? To what extent do these rates vary with the proximity to reservations and tribal lands? How do monetary sanctions reflect or amplify existing inequalities for Native Americans and other groups? We address the first two questions using administrative data and the third using in- 
Figure 1. County-Level Population Identifying as Native Americans

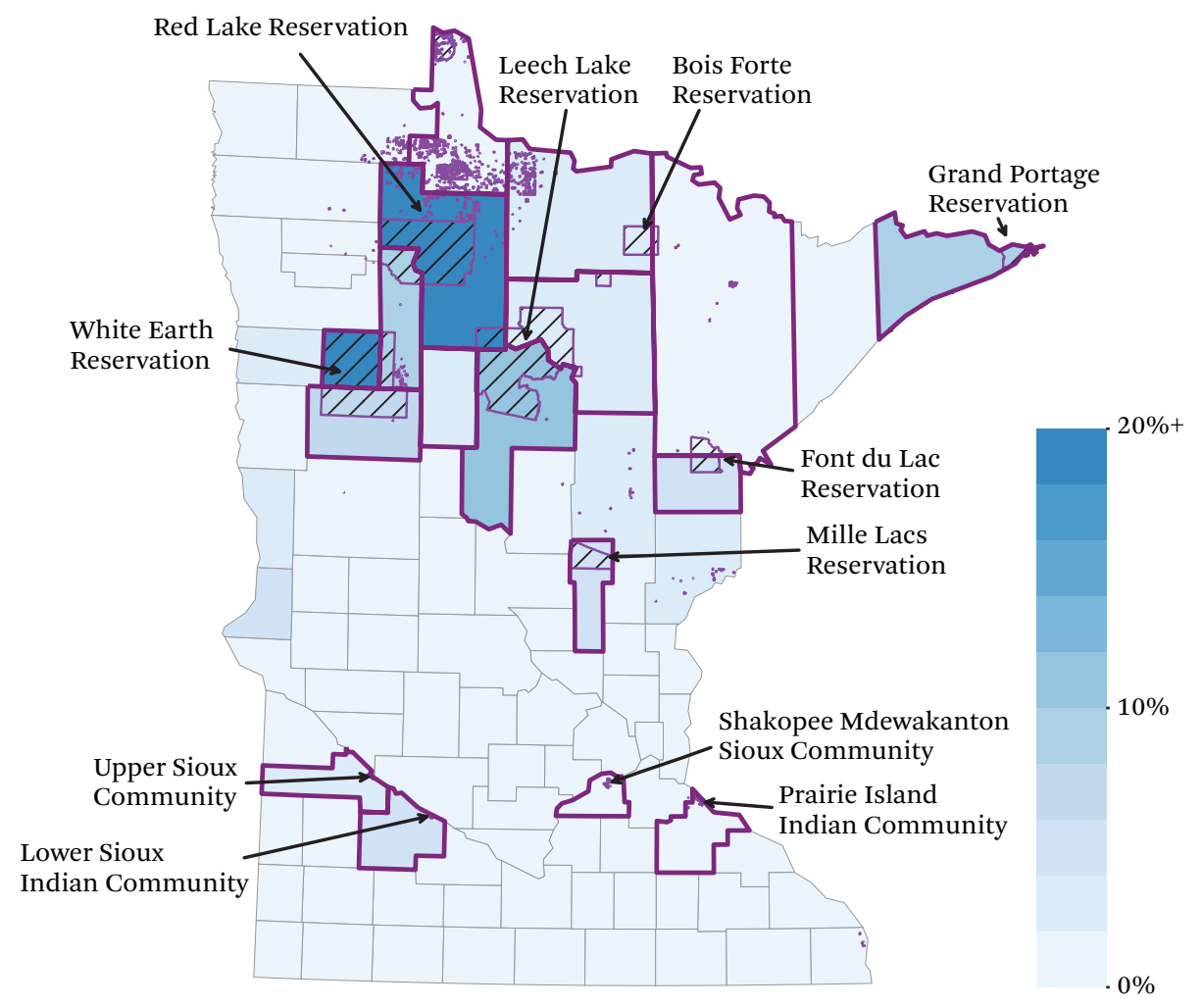

Source: US Census 2015.

terviews with both debtors and decisionmakers in the courts.

\section{DATA AND METHODS}

This article draws on data collected as part of the Multi-State Study of Monetary Sanctions, which began in the fall of 2015 (for more detail on the data collection strategies and approach for the larger project, see Harris, Pattillo, and Sykes 2022, this volume). Our findings are drawn from data collected and analyzed primarily by the Minnesota research team. These data include administrative criminal court data and interviews with court decision-makers and defendants from Minnesota in the northcentral part of the state. We first describe the distribution of tribal nations within the geographic context of this study.

\section{GEOGRAPHIC AND TRIBAL CONTEXT}

Of Minnesota's eighty-seven counties, seventeen share land at least in part with Indian res- ervations held by tribal nations (these counties are outlined in figure 1). In northern Minnesota, which is home to the majority of the state's American Indian population, thirteen counties stretching across the northern half of the state overlap with reservation land of seven Ojibwe (or Anishinaabe) tribal nations: Bois Forte Band of Chippewa, Fond du Lac Band of Lake Superior Chippewa, Grand Portage Band of Lake Superior Chippewa, Leech Lake Band of Ojibwe, Red Lake Nation, and White Earth Nation. The three largest reservations, Leech Lake, Red Lake, and White Earth, are clustered in the north-central part of the state. Additionally, four Minnesota counties share land with four Dakota communities: the Lower Sioux Community and the Upper Sioux Community in southwest of Minnesota, and the Prairie Island Indian Community and Shakopee Mdewakanton Sioux Community in the southeast. Based on HUD's approach to determining rural American Indian population (Pettit et al. 2014), 
37 percent of American Indians-or those who identify as American Indian or Alaska Native alone-in Minnesota live within reservation borders, and 61 percent-including those who live on reservations-live in the seventeen reservation counties (Census Bureau 2015).

\section{ADMINISTRATIVE CRIMINAL COURT DATA}

Administrative criminal court data were obtained from the Minnesota State Court Administrator's Office (SCAO). The data include all criminal and traffic cases filed in Minnesota criminal courts from 2004 through 2015, though we limit our sample to those cases filed from 2010 to 2015 because of issues with data quality for cases before 2010. Data are further limited to cases that were closed (sentenced) on or before August 2018. The administrative data extract includes a multitude of details at the case, charge, and person levels. The data include all charge severity levels in Minnesota, namely, petty misdemeanors (civil citations), misdemeanors, gross misdemeanors, and felonies. However, we subset our data to exclude parking violations for two reasons: first, they are mostly standardized and located in urban counties; second, they are much less likely to include race information given that they are payable without an appearance. Both reasons could systematically alter our descriptive means due to our imputation strategy, as we discuss. We similarly restrict our sample of individuals to only those with at least one misdemeanor charge in the 2004 to 2015 period because petty misdemeanors (such as speeding or minor traffic tickets) are mostly payable without an appearance.

Data on race are at the case level and based on self-report. Minnesota allows nearly all petty misdemeanors and certain misdemeanors to be paid online or through the mail rather than in person, and the court does not systematically collect self-reported race information in those instances. Because race is collected at the case level and not the person level, withinperson racial self-identification especially among American Indians, cannot be assumed to be static but instead can change over time (Liebler et al. 2017; Liebler, Bhaskar, and Porter 2016; Liebler and Ortyl 2014). We impute race within persons for cases that have missing race data. However, because race is not necessarily invariant within persons, we impute with the mode of the race distribution within persons. We restrict our sample to include only individuals with at least one misdemeanor charge because our within-person imputation strategy would impute race information on very lowlevel cases only for those individuals who also have higher level cases in their history, which is ostensibly correlated with race and place and could yield a distorted picture of race differences in fines and fees. Following imputation, the data included 1,520,006 cases ( 42 percent) without self-reported race information. These were not used in the analyses.

In the SCAO data, race and ethnicity identification are combined, resulting in an elevencategory nominal race measure. However, we combine the various missing categories into one group (Refused, Unavailable, Unknown), as well as combine Other, Multiracial, and Hawaiian or Pacific Islander into a larger Other categorization given the small numbers of cases in each of the groups. This results in a six-category race variable (Asian, Black, Hispanic, Native American, Other, and White).

Detailed ledger information on court fines and fees-or LFOs - was drawn from two data storage systems, the Minnesota Court Information System and the Violations Bureau Electronic System, that are included within the SCAO data extract. We aggregate both ordered and outstanding fine and fee amounts to the case level, resulting in measures of what fines and fees were ordered and how much of that amount was outstanding at the time of the data extract (August 2018). We do not include orders of restitution in our totals because the data are sparse with the majority of cases carrying a restitution order of $\$ 0$, and systematically missing from two Minnesota counties because of the nature of the data collection system.

\section{FIELDWORK}

Minnesota's judiciary is organized as a statefunded unified court system with only one level of trial court, the District Court (Ashman and Parness 1974). County-level district courts, which are organized within ten judicial districts, are trial courts that have original jurisdiction over all criminal matters, from parking or 
speeding tickets to the most serious felonies, and nearly all civil matters (Dosal 2007). Our research team selected six county district courts to conduct our fieldwork that represented a loose cross-section of the state. Of the six selected counties, two include the two largest cities in the state, two are suburban counties, one is in rural southern Minnesota where fourteen of every fifteen residents are White, and one is in north-central Minnesota where nearly one in four residents identify as American Indian (Census Bureau 2015).

From 2016 to 2019, our team conducted ethnographic fieldwork and interviews in these six Minnesota counties, including more than two hundred hours of courtroom observation, seventy interviews with defendants, and sixty-five interviews with court actors (for more details and background on the Multi-State Study of Monetary Sanctions and further discussion of the methodology and data collection process, see Harris, Pattillo, and Sykes 2022, this volume). Most Native Americans in Minnesota live in the north-central region of the state, and this region also includes the three largest reservations in Minnesota. Therefore, we focus primarily on data collected in north-central Minnesota, including interviews with ten legal debtors (or defendants) and fifteen court actors (or judges, prosecutors, defense attorneys, and probation officers). We supplemented our interviews with a focus group that included twelve public defenders, one defense investigator, and two defense staff. Focus group participants were recruited through convenience sampling and the session was conducted during a group lunch hour in the summer of 2017. We also spent nearly forty hours observing more than 250 criminal court cases in one northcentral county, taking field notes on the proceedings and recording the outcomes of nearly every case we observed. We supplemented our local data collection with additional interviews of debtors and court actors in other counties in Minnesota.

All of our qualitative data was transcribed and imported to NVivo for organization. As we reread our interview transcripts and court observation fieldnotes, we identified and coded pertinent themes that emerged. We focused primarily on the experiences of American Indian defendants and the specific consequences that monetary sanctions had on this population as they were described by debtors themselves and legal actors, coding for perceptions, experiences, and examples. Notably, it was common for judges, prosecutors, and probation officers we interviewed to candidly assert that Native American defendants did not experience racialized disadvantage in the criminal legal system in their jurisdiction, often using explicit colorblind language to suggest that the experiences of everyone in the system, regardless of racial or political identity, had analogous experiences (Bonilla-Silva 2009; Pruitt et al. 2018; Denis 2015). Our focus is on how Native American defendants experienced the American criminal legal system, how they interpreted those experiences, and how particular consequences may affect Native Americans more acutely than other groups. The findings thus privilege the voices of the defendants and public defenders because they often centered those issues in our interviews. For these reasons, we also do not include findings or analyses of tribal courts or their effects because they operate under the jurisdiction and purview of wholly separate and sovereign tribal nations.

\section{TERMINOLOGY}

Throughout this article, as noted earlier, we use the terms American Indian, Native American, $\mathrm{Na}$ tive, and Indigenous. These terms are often used interchangeably, even among Native people, and no single term is agreed upon across all tribal communities. We use Indigenous as a comprehensive term to designate first peoples, and Native American in reference to those in the United States in particular. American Indian is widely used as a racial category, but it is perhaps as much-if not more so-a political designation, though an admittedly unrefined one. Each tribal nation is a sovereign nation, therefore distinct tribal identifiers are generally preferred over these labels, but the judiciary does not collect this level of detail. We use the identifier American Indian to highlight political status (though one given by the United States, it has been adopted and reimagined by tribes). We also capitalize these terms following other proper nouns used in reference to groups of people (Canadian, Mexican, and Minnesotan). 
We center reservations in our analysis and use the term Indian Country to refer to reservations and those Minnesota counties that overlap with those reservations. The term is used regularly in colloquial speech among American Indian communities, often with pride, to refer not only to reservations and trust lands but also ancestral homelands and "wherever American Indian spirit, pride, and community are found" (NCAI 2019). Indian Country encompasses a larger geographic area than the United States' legal definition of Indian country (lowercase c), ${ }^{2}$ which narrowly refers to Indian reservations and other trust lands. Further, given that contemporary Indian Country-like anywhere else-contains mixed race and mixed tribally affiliated citizens, we cannot assume that every Native person represented in our administrative data or whom we interviewed was Ojibwe in northern Minnesota, Dakota in southern Minnesota, or even from a geographically proximal reservation or community.

\section{FINDINGS}

We begin by describing the monetary sanctions burden for Native Americans relative to other groups in Minnesota. We then draw on our interviews and court observations to add additional layers of context to explore how monetary sanctions directly and indirectly exacerbate spatial and political inequalities. We demonstrate that in areas with larger Indigenous populations in Minnesota, the LFO burden for American Indians is higher than for other groups. We also find that these rural areas not only have higher rates of overall poverty and fewer resources for Native American residents, but also fewer criminal court sentencing options, leading to both harsher punishments and harder landing surfaces before and after criminal court involvement.

Monetary sanctions imposed directly by the courts are composed of four main parts: the fine, the criminal surcharge, any court fees, and restitution. We focus here on the combination of the first three components because restitution data is limited in the two largest counties in our dataset. Minnesota statutes do not set specific fine amounts for offenses but do pro- vide general ranges. Maximum fine amounts for felony offenses are typically fixed by each individual offense's controlling statute. The highest maximum fine in current statute is $\$ 1,250,000$ for importing controlled substances across state borders (M.S. $\S 152.0261$ ), followed by a maximum fine of $\$ 1,000,000$ for firstdegree controlled substance sales or possession ( $§ 152.021)$, concealing criminal proceeds (§ 609.497), and racketeering ( $§ 609.904)$. If a maximum fine is not otherwise fixed by statute, the maximum fine is $\$ 10,000$ ( $§ 609.03)$. Gross misdemeanors are intermediate level criminal offenses that can carry a maximum sentence of one year in jail or a $\$ 3,000$ fine, or both (§§ 609.03 subd. 2; 609.02 subd. 4). Misdemeanors, the lowest criminal offense level, can be sentenced to a maximum of ninety days in jail and a $\$ 1,000$ fine $(\S \S 609.02$ subd. $3 ; 609.02$ subd. 3). Petty misdemeanors, which are civil and not criminal violations, carry a maximum fine of $\$ 300$ ( $\$ 609.02$ subd. 4a). Minimum fine amounts for all offense levels are equal to 30 percent of the maximum fine allowed by law $(\S$ 609.101 subd. 2-4). However, if the defendant qualifies for a public defender ( $§ 611.17$ ), is indigent, or payment would create an undue hardship, the court may reduce the fine to no less than $\$ 50$ (§ 609.101 subd. 5(b)). Additionally, since 2001, district court judges have also had the option to allow the defendant to perform community service in lieu of paying a fine (Laws of Minn. 2001, c. 71, sec. 4).

In addition to the fine, surcharges and court fees are regularly imposed by Minnesota courts. Courts are statutorily required to impose a criminal surcharge on each case $(\S 357.021$ subd. 6). The amount of the surcharge has changed over time but has been $\$ 75$ since 2009 . Unlike fines, courts are not technically allowed to waive any part of the surcharge or convert it to community service. Court fees can include county sheriff fees, controlled substance fees, felony fees, and others that vary widely from county to county and city to city. Many of these fees are set by county boards or municipal governments rather than state statute. The law library fee, however, is required statewide and ranges from $\$ 0$ to $\$ 15$ depending on the county. 
Table 1. LFO Orders and Debt by Region

\begin{tabular}{|c|c|c|c|c|c|}
\hline \multirow[b]{2}{*}{ County Designation } & \multirow[b]{2}{*}{$\mathrm{N}$} & \multicolumn{2}{|c|}{ Order } & \multicolumn{2}{|c|}{ Debt } \\
\hline & & Mean & Median & Mean & Median \\
\hline 6-County Metro & $1,244,746$ & $\$ 230$ & $\$ 159$ & $\$ 68$ & $\$ 0$ \\
\hline Indian Country “Rural” & 261,430 & $\$ 272$ & $\$ 196$ & $\$ 67$ & $\$ 0$ \\
\hline Non-Indian Country “Rural” & 583,564 & $\$ 268$ & $\$ 176$ & $\$ 54$ & $\$ 0$ \\
\hline Statewide & $2,089,740$ & $\$ 246$ & $\$ 164$ & $\$ 64$ & $\$ 0$ \\
\hline
\end{tabular}

Source: Authors' tabluation.

Figure 2. Mean LFO Order per Case by County (2010-2015)

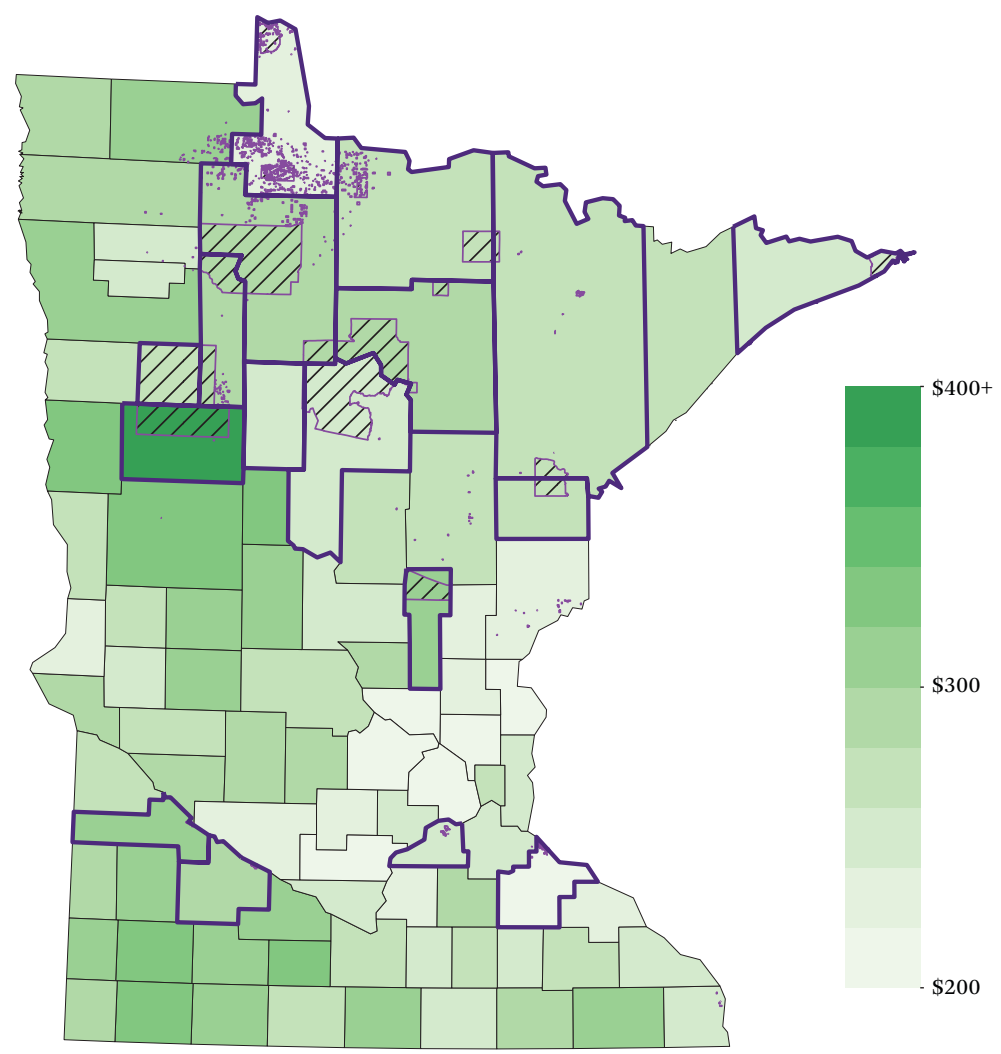

Source: Authors' tabulation.

Notes: Amounts adjusted to January 2018 Dollars.

\section{NATIVE AMERICANS AND}

MONETARY SANCTIONS

For the descriptive analyses, we combine all fines, fees, and surcharges imposed by the court at the case level. To consistently compare dollar amounts over time, we further adjust dollar amounts to January 2018 dollars to adjust for inflation. In table 1 , we show average and median LFOs imposed and outstanding LFO debts. Across more than two million cases filed in Minnesota from 2010 to 2015, the mean and median LFO order by case statewide was \$246 and \$164, respectively. However, we find that LFO amounts clearly differ by geography. Courts in the six-county Twin Cities metropolitan region, which includes Anoka, Carver, Da- 
Figure 3. Mean LFO Debt Per Case by County, 2010-2015

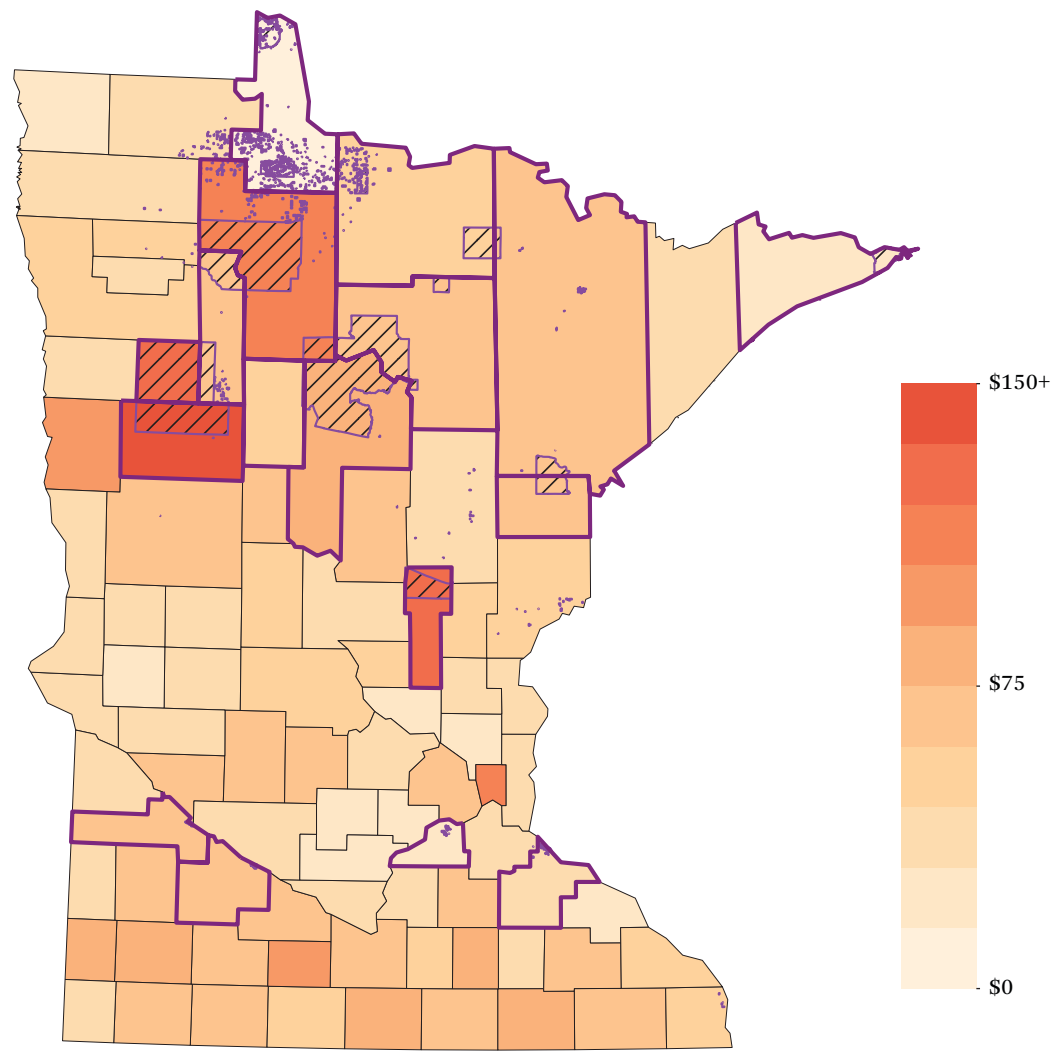

Source: Authors' tabulation.

Notes: Amounts adjusted to January 2018 dollars.

kota, Hennepin, Ramsey, and Washington, handle the bulk of the state's criminal cases. ${ }^{3}$ During this period, metro judges imposed an average total of $\$ 230$ in monetary sanctions that had a median LFO order of \$159. Consistent with the findings of O'Neill, Smith, and Kennedy (2022, this volume), we find that rural counties - and especially those in Indian Country-are more punitive: the average LFO in nonmetro counties, including those that overlap with Indian Country and those that do not, was around \$40 more than metro counties, and the median case was $\$ 37$ higher in Indian Country and $\$ 17$ higher in non-Indian Country. For many defendants facing financial hardship, the added debt of an LFO can be difficult to pay off quickly, if ever. We again find distinct geographic variation: in the six-county metro, the mean LFO debt at the case level is $\$ 68$, relative to $\$ 54$ in non-Indian Country counties and \$67 in Indian Country counties.

The relationship between proximity to a reservation and LFO debt becomes even more evident at the county level. In figures 2 and 3, we present average LFO order and average LFO debt at the case level by county, respectively. We include both figures not to directly compare LFO orders with LFO debt, but to show the geographic variation in each measure separately. The metro counties are shaded slightly lighter than the counties in the rest of the state, which is consistent with table 1 . In these 
Figure 4. Mean LFO Order and Debt by Race

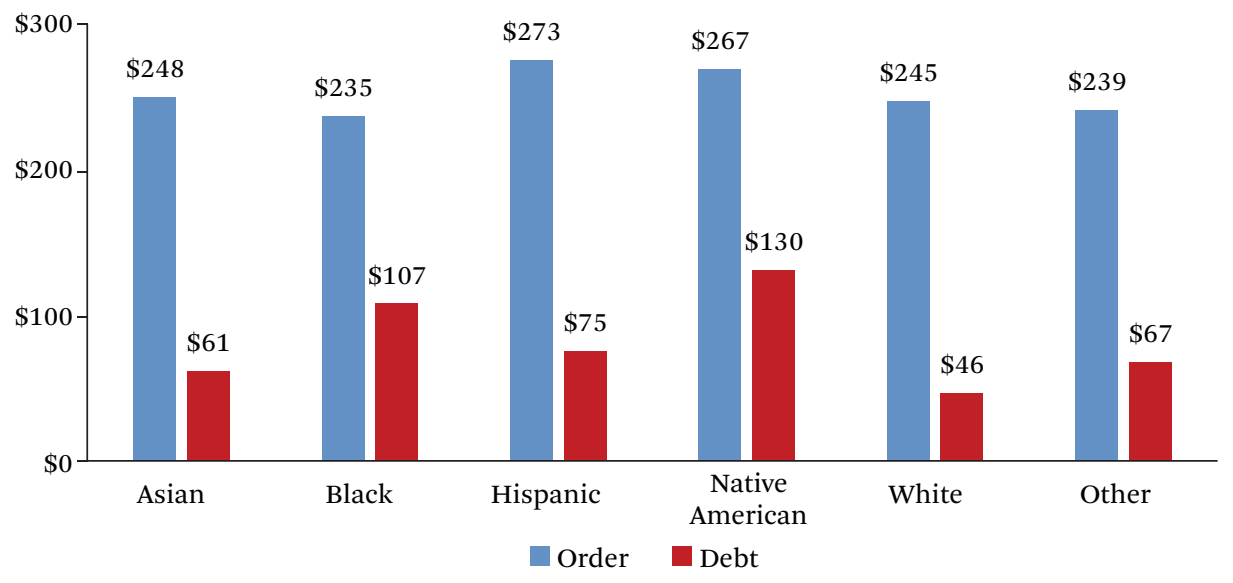

Source: Authors' tabulation.

Figure 5. Mean LFO Order by Race and County Category

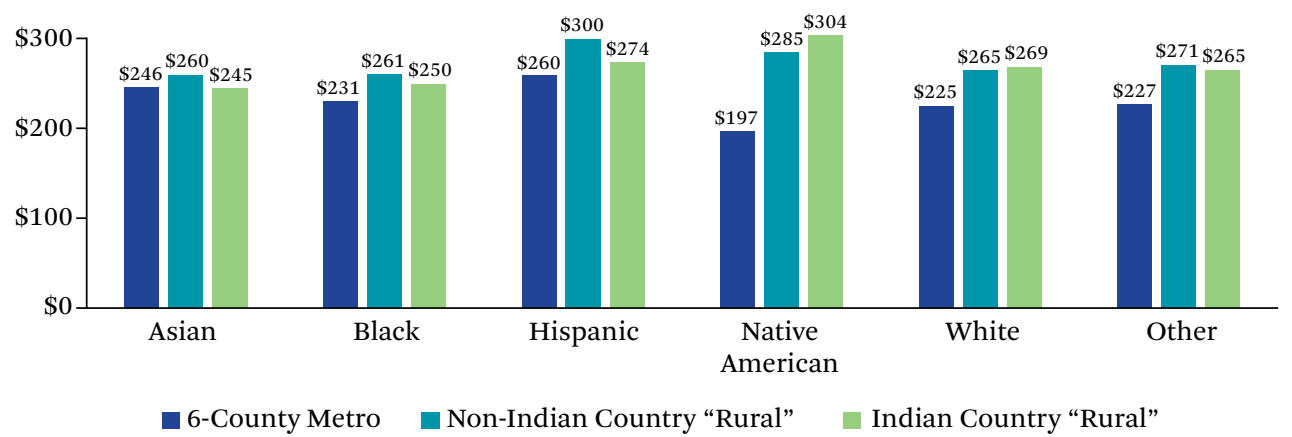

Source: Authors' tabulation.

nonmetro counties, we find only slight variation in mean LFOs from county to county. However, reservation proximity becomes more salient when we compare mean LFO debt across counties, as in figure 4 . The four counties that immediately stand out are Becker, Beltrami, Mille Lacs, and Mahnomen in the northcentral part of the state and that significantly overlap with or are immediately adjacent to large reservations.

We also find disparities in LFOs across racial and ethnic groups. Figure 5 shows average ordered LFOs and outstanding LFO debt by raceethnicity. Relative to other groups, Native Americans are second only to Hispanic defendants in LFO orders but carry significantly larger debt loads than other groups. On average, courts impose \$267 in total fines, fees, and surcharges in cases with Native American defendants, compared to $\$ 273$ for defendants who identify as Hispanic, \$245 for White, \$248 for Asian, and \$235 for Black. At the case level, Native Americans defendants also have higher average outstanding LFO balances than other defendant groups. In cases with Native American defendants, the average LFO debt is $\$ 130$ statewide, which is 21 percent higher than Black defendants, the next highest group.

In figures 5 and 6, we consider the relationship between reservation proximity and raceethnicity. Consistent with our findings from table 1 , the six-county metro area has lower overall monetary sanctions than nonmetro counties. Outside the metro area, Native Americans defendants receive on average among the highest LFOs of any racial or ethnic group, and 
Figure 6. Mean LFO Debt by Race and County Category

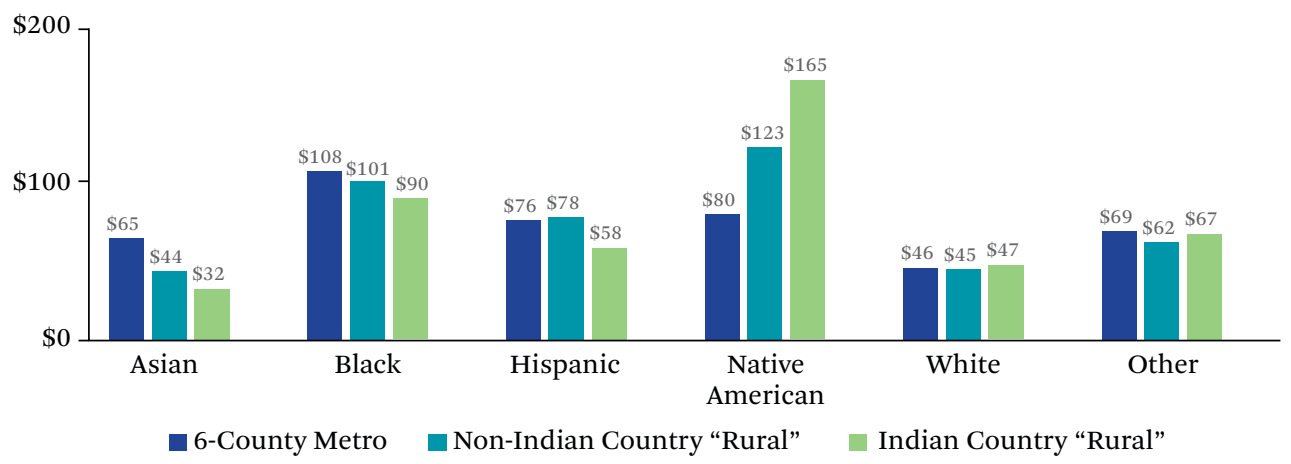

Source: Authors' tabulation.

the highest in counties that overlap with a reservation.

The racial-ethnic differences by geography are more striking - and perhaps more consequential-when we examine outstanding LFO debt among groups. Cases with Native American defendants in nonmetro counties, where residents are more likely to be affected by rural poverty and lack of resources, and have much larger outstanding LFO balances from LFOs imposed in the criminal court system than any other group, most conspicuously in counties that overlap with reservations. In these counties, the average outstanding LFO balance in cases with Native American defendants is often a multiple of other racial groups: 515 percent the average White outstanding balance, 284 percent the average Hispanic balance, and 183 percent the average Black balance. Thus, in areas proximal to reservations, Native American defendants are subject to greater monetary sanctions and more likely to carry greater LFO debt loads, all while living in greater poverty and with less access to resources. Further, these findings suggest that the higher LFO orders and debts that Native Americans experience are not due solely to the higher distribution of Indigenous peoples in Minnesota's rural counties, but also to a specific reservation-based experience of greater punitiveness and debt. To add context to these findings, we next turn to our fieldwork in the north-central region of Minnesota to expand on how poverty, spatial isolation, and lack of resources and opportunities compounds disparities for Native American communities in the areas in and around Indian Country.

The findings presented are situated within one geographic and historical context with a particular legacy of settler-Indigenous relations that may not be applicable to other areas. Because of the geographic location of historically resource-rich waterways in the Pacific Northwest (Taylor, Stein, and Jolivette 2011), for example, the Native American population in Washington State-including those living on or near reservations - is much more urban or closer to urban areas. In fact, a majority of reservations in Washington are near or inside the coastal metropolitan area counties. This includes King and Pierce Counties, which include Seattle and Tacoma, respectively. Applying the same geographic categorization approach as used in this study would not be appropriate in Washington because it would include significant urban areas. Further, the literature shows that urban Indigenous populations face a different set of challenges (Weaver 2012), which may be particularly acute in an area that features an pressing housing crisis such as Seattle, hinting at potentially different dynamics of settler colonial dispossession (Sparks 2017). Jessica Mogk and her colleagues (2020) find significant evidence of a homelessness-incarceration nexus in Seattle, and Daniel Boches and his coauthors (2022, this volume) offer additional evidence of the reciprocal role that monetary sanctions play in housing instability. A more complete analysis of the relationship between urban and rural within 
the state of Washington is outside the scope of this contextual comparison. We therefore highlight the need for rigor and care when generalizing to capture the fullness of the historical processes of dispossession and erasure of Native Americans. Nonetheless, a state-level analysis of automated criminal court data in Washington shows that monetary sanctions in Washington follow a broadly similar pattern to Minnesota. Although Native Americans have the fourth highest average LFO order, they have the second highest average LFO debt.

\section{POVERTY AND SPATIAL ISOLATION}

Throughout our interviews in north-central Minnesota, pervasive poverty was identified as a consistent strain on the community. A district court judge who had been on the bench for more than a decade explained: "We're a poor community. We're very poor, and so we don't have a lot of [well off] folks. 'Well off' is a relative term in [this county]." Likewise, one prosecutor said, "We are in one of the poorest parts of the state of Minnesota," a characterization echoed by nearly every court actor and legal debtor we spoke with.

Most described a general lack of opportunities and resources in this rural area of northcentral Minnesota, an area that is home to the majority of the state's Native American population outside the Twin Cities and to three of its largest reservations. The poverty rate of counties that include significant portions of reservations is nearly 15 percent, more than 6 percentage points higher than the rest of the state and 5 points higher than the statewide average.

Financial strain was particularly acute for people involved with the criminal justice system in northern Minnesota. When describing how monetary sanctions were applied in their local jurisdiction, every public defender interviewed took issue with how indiscriminately fines and fees were levied against their clients. To some respondents, judges had become seemingly indifferent to the financial pressures their clients face. Robin, a White woman in her late twenties who had been a public defender in two north-central counties for almost five years, described her frustration: "I think in [this judicial district] judges do not understand what it means to be poor, and what 150 bucks could mean to somebody. I think the judges are starting to glaze over more as we talk about, 'Look, there's these other payments that people have to make, payments to the jail, payments to probation, payments for chemical dependency. All of these things really start to add up.' I don't know. I think the judges are like, 'Ah, not my problem.' And so that's really frustrating because it's just ... it's not working."

Not only did judges not appreciate the precarious financial state many of her clients were in, Robin and many of her colleagues also did not believe that judges appreciated how the various costs associated with their sentencing practices, such fees required to satisfy probation conditions or stints in the local pay-forstay county jail, could rapidly accumulate.

Another public defender who also practiced across two counties, Jayne, suggested that local judges did in fact recognize that most defendants were not financially stable. In describing how her clients have dealt with monetary sanctions they likely couldn't pay, she explained, "Generally, we see the fines and fees go to collections. Because they prioritize paying their CD [Chemical Dependency] assessment, and paying for treatment, and paying for [domestic abuse programming]. Because these are the things that, if they don't do, they're going to see immediate jail consequences. I think people prioritize those, and then the fines and fees typically will go to collections and are paid last." According to Jayne, prioritizing financial obligations for programming over fines and feeswhich could be sent to collections-was encouraged by judges, "That's usually the advice of the judge: pay this stuff first and then pay the fines and fees later."

For defendants, this approach may have been preferable. During our focus group with a dozen public defenders who practiced in the area, a White woman in her thirties who had represented indigent clients for more than a decade characterized a conversation she has often had with her clients over the years. She would ask them if they were worried about whether debts in collections would affect them down the road: "What about your ability to get an apartment and this going to collections? What about you being able to get a loan?" In response, her clients would say that they "al- 
ready have debt issues so honestly what's going to happen if this goes to collections?" As this public defender summarized it, "They're at the point where they can't even focus on that because if they do they're taken out of survival mode. Because they just can't even pay attention to that because it's too much. They're focused on basic needs ... shelter, food, and then also making sure they're in safe space. And sometimes they even have to waffle on that. So going to collections? That's the least of their concerns. They can't be concerned about that."

For many in rural impoverished areas, compounding debts and perpetual balances in collections not only have become an expected part of life, but also contribute to a sense of alienation and despair. Often in court observations and interviews, defendants described how their financial difficulties rippled through their lives, creating barriers and contributing to their struggles with addiction. For example, Samuel, a Native American man in his twenties grew up in poverty and had been involved with the criminal justice system since he was a teenager. When asked about the impact monetary sanctions have had on him and those in his life, he was blunt: "It gets pretty rough and people go downhill and nobody gives a shit." He went on to describe it as "A big hole you get yourself into and cannot get out." He continued, "My whole life I've been dealing with fines and the struggle with the system.... It plays a big role in your future too. Everything that you do in your past. You can't get housing. You can't, you know. It just sucks all around. So, if you're trying to raise a family and you got all this crap going on. If you can't land a decent job, you're not going to make it."

Receiving an LFO was not just a single data point for Samuel. Instead, it was part of a long sequence of relentlessly accruing, overwhelming financial strain that defined his access to resources and prevented him from breaking free.

\section{FEW RESOURCES AND LITTLE}

\section{ACCESS TO TRANSPORTATION}

This area of the state has comparatively few public and private resources, particularly resources relied on by the criminal court process. For example, although Minnesota provides a relatively robust path for funding outpatient and inpatient substance use treatment for low-income Minnesotans through its Rule 25 Assessment program, the waitlist for an assessment is often lengthy. We spoke with a public defender who had clerked after law school in the Twin Cities metro area. She compared her experience in the metro area with her current north-central Minnesota county, saying that the typical wait in the Twin Cities for a Rule 25 was around ten days, but up north she has clients "sitting in jail for months at a time waiting for a Rule 25 to get done, and they haven't gotten done." Even when a defendant was assessed as eligible for treatment funding, this rural area of the state had very few substance use treatment program options. While we were in the field, only two outpatient treatment programs and two inpatient treatment programs were within an hour's drive, and they typically had waitlists going out for months. For those with co-occurring disorders, the closest program is either the Twin Cities or Duluth, both several hours away.

In fact, because of the low population density in this part of the state, access to transportation is vital. As a public defender described it, "[Towns are] far apart, they're smaller, and then there's times like now where if you go outside, you'll die. You can't get around without reliable transportation." Crucially, though, Minnesota courts automatically suspend driver's licenses for most people with unpaid monetary sanctions for most offenses. The state's Driver and Vehicle Services division (Minnesota's Department of Motor Vehicles) also requires those with multiple violations for driving without insurance to show proof that they have prepaid at least six months of insurance before they are eligible to have their licenses reinstated. Residents without valid registration, car insurance, or valid licenses who are looking for employment, for example, face the difficult choice of either searching for work in a small geographic area with few opportunities or risk driving illegally for a better opportunity to find a job.

According to some defendants, it has really not been much of a choice. For instance, a young Native American couple, Ashley and Timothy, spoke about the process of getting their licenses back after being suspended for 
unpaid fines. Ashley, who had been a stay-athome mother of two young children, said that to get her license back, she "got a job and I got my first check and I used the whole check just to pay it off." She continued,

ASHLEY: It was like $\$ 600.00$, almost seven hundred bucks. And then I had to pay for insurance, which was another thing. I had to have six months of insurance just in order to be able to get my license back. So I had to show proof of that, and that was another ...

Тімотну: \$600. It was like six or eight.

ASHLEY: It was like $\$ 800$ almost. I don't know, something like that, so it was pretty expensive.

But for Timothy, who estimated that he would have to pay a total of $\$ 4,000$ in unpaid monetary sanctions across multiple counties to get his license reinstated, paying off his LFOs simply was not feasible. As Ashley told us, "So I got it paid off and now I'm good. I don't have to worry about it. I just got to worry about his." We asked Timothy, who had an extensive criminal history and was on probation, how he got to his job:

ASHLEY: To be completely honest, like he drives.

TIмотнY: I have to.

ASHLEY: We have to.

Tімотну: How often is somebody just going to get up at two o'clock in the morning and bring you to work?

INTERVIEWER: Right.

ASHLEY: It's three hours away.

INTERVIEWER: You work three hours away? Tiмотну: Yeah. I drive to [a mid-size city].

ASHLEY: And then from [that city] they go whatever they're going to go.

TімотнY: From there I'm okay because they've got a nice driver with work trucks we take. But, you know, just the risk from me going from my house to [that city] -if I get another ticket, I go to prison, so just from that alone I'm risking it.

Although Timothy's daily commute is likely an outlier, the struggle associated with not hav- ing a valid license or reliable transportation is not. Nearly every court actor we spoke with reported that transportation access, and specifically driver's license suspension for unpaid monetary sanctions, was a widespread issue in the local community, especially for those who live on a reservation.

\section{DISCUSSION AND CONCLUSION}

Communities of color are often hardest hit by court-ordered legal financial obligations, given inequities in both punishment and wealth. However, these analyses have only rarely focused on the experiences of American Indians, a group often excluded in comparative analyses of criminal justice outcomes and experiences among racial and ethnic groups. In this exploratory analysis of Native Americans and monetary sanctions, we contribute to the growing body of work that has begun to address the shortcoming.

First, consistent with Bing and colleagues (2022, this volume), we find that relative to other racial and ethnic groups in Minnesota, Native Americans and Hispanics are subject to among the largest overall LFOs in criminal court, but Native Americans carry the largest average LFO debt loads. Second, we find descriptive evidence that Native Americans are particularly penalized when proximal to tribal lands. On average, judges in these counties impose LFOs in cases with Native defendants that are 12 percent higher than the mean. Even more concerning, the average outstanding LFO debt on cases with Native defendants is upward of \$165-more than 80 percent higher than the next highest racial group and more than four times higher than the average debt for White defendants.

Third, monetary sanctions exacerbate existing poverty and spatial isolation in rural areas, compounding and further entrenching historical, systemic disadvantages that Native communities already face. Interviewees described an area of Minnesota with few resources and mounting legal financial debts that contributed to the cycle of poverty. Driver's license suspensions for unpaid LFOs were regularly cited as a primary impediment. Paired with few transportation options and limited employment prospects, especially to and from reservations and 
tribal lands, many Native American residents were faced with the choice of driving illegally or being able to support their families. On the other end, the interviews also illustrate how monetary sanctions magnify poverty as friends, families, and communities are affected by their effects (Harris 2016).

Our findings on monetary sanctions among American Indians in Minnesota are descriptive and exploratory; nonetheless, these findings support the premise that settler colonialism is indeed a structure, not an event (Wolfe 1999). This study suggests that though the mechanisms may have shifted or become less perceptible, the American settler colonial project has adapted to neoliberal financialization through the growth of criminal justice resource extraction. Historically, settler governments extracted resources from tribal nations through violence, coercion, displacement, and assimilation (Wolfe 1999; Veracini 2010; Glenn 2015; Steinman 2016); today, these entities draw financial resources disproportionately from American Indians through the privately targeted and less visible criminal legal system. Put another way, our findings underscore the continuity of settler colonial domination and point to the ways that contemporary dispossession can operate in much less perceptible ways to ensure structural inequalities. Although settler colonial extraction historically targeted "the tribe" as an entity, we suggest that it is sustained today in part by individualized predation of American Indians. Thus the fundamental settler colonial economy of dispossession persists.

A technique of settler colonial dispossession, the popular discourse that frames monetary sanctions as colorblind, apolitical, or bureaucratic proceduralism may work to inhibit a broader understanding of the ways settler colonial domination creates the material conditions of possibility for Native "indebtedness" in the first place (Denis 2015). It also further masks the historical conditions-such as land theft, extermination, and assimilation-that are foundational to contemporary social problems and inequalities in American Indian communities (Moreton-Robinson 2018). By missing, disconnecting, or ignoring the ways settler colonial dispossession is both enduring and foundational to disparate outcomes in the U.S. crim- inal legal system, such as the LFO debt loads among Native people in Minnesota, American Indian political struggles and resistance may be stigmatized or dismissed as illogical or even criminal. Consequently, by locating American Indian experience within a broader historical context of settler colonialism, future work in this area would be strengthened by drawing on what Joshua Page and Joe Soss (2017) refer to as a "criminal justice predation" frame, which encourages seeing the various revenue projects of the U.S. criminal justice within a broader context of the historical dispossession of subjugated communities.

As other scholars observe, settler colonial domination is structured and reproduced through various applications of debt. The evidence from this study suggests that individualized monetary sanctions likely have communal and political ramifications for Native communities, operating as contemporary instruments of the enduring structure of settler colonialism. We invite future researchers to investigate what these ramifications mean for sovereignty, political status, and cultural perseverance to build a more thorough, comprehensive understanding of the modes of contemporary settler colonialism.

\section{REFERENCES}

Akee, Randall, Sue K. Stockly, William Darity Jr., Darrick Hamilton, and Paul Ong. 2017. “The Role of Race, Ethnicity and Tribal Enrolment on Asset Accumulation: An Examination of American Indian Tribal Nations." Ethnic and Racial Studies 40(11): 1939-960.

American Presidency Project. 2021. “Theodore Roosevelt: First Annual Message." Accessed July 4, 2021. https://www.presidency.ucsb.edu/node /206187.

Ashman, Allan, and Jeffrey A. Parness. 1974. "The Concept of a Unified Court System." DePaul Law Review 24(1)(Fall): 1-41.

Beardall, Theresa Rocha, and Raquel Escobar. 2016. "What Then Remains of the Sovereignty of the Indians: The Significance of Social Closure and Ambivalence in Dollar General v. Mississippi Choctaw." Indigenous Peoples' Journal of Law, Culture and Resistance 3(1): 3-38.

Bing, Lindsay, Becky Pettit, and Ilya Slavinski. 2022. “Incomparable Punishments: How Economic In- 
equality Contributes to the Disparate Impact of Legal Fines and Fees." RSF: The Russell Sage Foundation Journal of the Social Sciences 8(2): 118-36. DOI: https://doi.org/10.7758/RSF.2022 8.2.06.

Boches, Daniel J., Brittany T. Martin, Andrea Giuffre, Amairini Sanchez, Aubrianne L. Sutherland, and Sarah K.S. Shannon. 2022. “Monetary Sanction and Symbiotic Harms" RSF: The Russell Sage Foundation Journal of the Social Sciences 8(2): 98-115. DOI: https://doi.org/10.7758/RSF.2022 8.2.05.

Bonilla-Silva, Eduardo. 2009. Racism Without Racists: Color-Blind Racism and the Persistence of Racial Inequality in America, 3rd ed. Lanham, Md.: Rowman and Littlefield.

Byrd, Jodi A., Alyosha Goldstein, Jodi Melamed, and Chandan Reddy. 2018. “Predatory Value: Economies of Dispossession and Disturbed Relationalities." Social Text 36(2): 1-18.

Carson, E. Anne. 2020. "Prisoners in 2019." BJS Bulletin NCJ 255115. Washington: U.S. Department of Justice, Bureau of Justice Statistics.

Chang, David A. 2011. “Enclosures of Land and Sovereignty: The Allotment of American Indian Lands." Radical History Review 109: 108-19.

Corntassel, Jeff, and Richard C. Witmer. 2008. Forced Federalism: Contemporary Challenges to Indigenous Nationhood. Norman: University of Oklahoma Press.

Cunneen, Chris, and Juan Marcellus Tauri. 2019. “Indigenous Peoples, Criminology, and Criminal Justice," Annual Review of Criminology 2(1): 359-81.

Deloria, Vine, Jr., and Clifford M. Lytle. 1983. American Indians, American Justice. Austin: University of Texas Press.

Denis, Jeffrey S. 2015. “Contact Theory in a SmallTown Settler-Colonial Context: The Reproduction of Laissez-Faire Racism in Indigenous-White Canadian Relations." American Sociological Review 80(1): 218-42.

Dewees, Sarah, and Benjamin Marks. 2017. "Twice Invisible: Understanding Rural Native America." Research note no. 2. Nashville, Tenn.: First Nations Development Institute.

Dosal, Sue. 2007. "Transition and Transformation: The Minnesota State Funding Project." Court Manager 22(1)(Spring): 18-25.

Eason, John M. 2017. Big House on the Prairie: Rise of the Rural Ghetto and Prison Proliferation. Chicago: University of Chicago Press.
Fink, Elizabeth Hope. 2020. "Sense and Census Building: Capturing Tribal Realities in the U.S. Census." Washington University Journal of Law and Policy 62: 201-26.

Franklin, Travis W. 2013. "Sentencing Native Americans in US Federal Courts: An Examination of Disparity." Justice Quarterly 30(2): 310-39.

Glenn, Evelyn Nakano. 2015. “Settler Colonialism as Structure: A Framework for Comparative Studies of U.S. Race and Gender Formation." Sociology of Race and Ethnicity 1(1): 54-74.

Gottschalk, Marie. 2020. "Caught in the Countryside: Race, Class, and Punishment in Rural America." In Rethinking Class and Social Difference, vol. 37, edited by Barry Eidlin and Michael A. McCarthy. Bingley, UK: Emerald Publishing.

Harris, Alexes. 2016. A Pound of Flesh: Monetary Sanctions as Punishment for the Poor. New York: Russell Sage Foundation.

Harris, Alexes, Heather Evans, and Katherine Beckett. 2011. "Courtesy Stigma and Monetary Sanctions: Toward a Socio-Cultural Theory of Punishment." American Sociological Review 76(2): 234-64.

Harris, Alexes, Mary Pattillo, and Bryan L. Sykes. 2022. "Studying the System of Monetary Sanctions." RSF: The Russell Sage Foundation of the Social Sciences 8(1): 1-33. DOI: https://doi.org /10.7758/RSF.2022.8.1.01.

Hartney, Christopher. 2008. Native American Youth and the Juvenile Justice System. Oakland, Calif.: National Council on Crime and Delinquency,

Hartney, Christopher, and Linh Vuong. 2009. Created Equal: Racial and Ethnic Disparities in the US Criminal Justice System. Oakland, Calif.: National Council on Crime and Delinquency.

Kim, Jodi. 2018. "Settler Modernity, Debt Imperialism, and the Necropolitics of the Promise." Social Text 36(2): 41-61.

Lakota People's Law Project. 2015. “Native Lives Matter." February. Accessed August 17, 2021. https://s3-us-west-1.amazonaws.com/lakota -peoples-law/uploads/Native-Lives-Matter -PDF.pdf.

LaVelle, John P. 1999. “The General Allotment Act 'Eligibility' Hoax: Distortions of Law, Policy, and History in Derogation of Indian Tribes." Wicazo Sa Review 14(1): 251-302.

Liebler, Carolyn, Renuka Bhaskar, and Sonya R. Porter. 2016. “Joining, Leaving, and Staying in the American Indian/Alaska Native Race Category 
Between 2000 and 2010." Demography 53(2): 507-40.

Liebler, Carolyn, and Timothy Ortyl. 2014. “More Than One Million New American Indians in 2000: Who Are They?" Demography 51(3): 110130.

Liebler, Carolyn, Sonya R. Porter, Leticia E. Fernandez, James M. Noon, and Sharon R. Ennis. 2017. “America's Churning Races: Race and Ethnicity Response Changes Between Census 2000 and the 2010 Census." Demography 54(1): 259-84.

Martin, Case. 2018. Relentless Business of Treaties: How Indigenous Land Became US Property. St. Paul: Minnesota Historical Society Press.

Martin, Karin D., Bryan L. Sykes, Sarah Shannon, Frank Edwards, and Alexes Harris. 2018. “Monetary Sanctions: Legal Financial Obligations in U.S. Systems of Justice." Annual Review of Criminology 1(1): 471-95. DOI: https://doi.org/10.1146 /annurev-criminol-032317-091915.

Minnesota Department of Corrections. 2020. "Adult Prison Population Summary as of 01/01/2020." St. Paul: Minnesota Department of Corrections. Accessed August 17, 2021. https://mn.gov/doc /assets/Adult\%20Prison\%20Population\%20 Summary\%201-1-2020_tcm1089-418232.pdf.

Mogk, Jessica, Valerie Shmigol, Marvin Futrell, Bert Stover, and Amy Hagopian. 2020. “CourtImposed Fines as a Feature of the Homelessness-Incarceration Nexus: A CrossSectional Study of the Relationship Between Legal Debt and Duration of Homelessness in Seattle, Washington, USA." Journal of Public Health 42(2): 107-19.

Moreton-Robinson, Aileen. 2015. “White Possession and Indigenous Sovereignty Matters." In The White Possessive: Property, Power, and Indigenous Sovereignty. Minneapolis: University of Minnesota Press.

Murphy, Michael Warren. 2018. "'No Beggars Amongst Them': Primitive Accumulation, Settler Colonialism, and the Dispossession of Narragansett Indian Land." Humanity \& Society 42(1): 4567.

National Congress of American Indians (NCAI). 2019. “NCAI Response to Usage of the Term, 'Indian Country." Accessed August 17, 2021. https://www.ncai.org/news/articles/2019/12/27 /ncai-response-to-usage-of-the-term-indian -country.

Nielsen, Marianne O. 2009. “Introduction to the
Context of Native American Criminal Justice Involvement." In Criminal Justice in Native America, edited by Marianne O. Nielsen and Robert A. Silverman. Tucson: University of Arizona Press.

Norris, Tina, Paula L. Vines, and Elizabeth M. Hoeffel. 2012. The American Indian and Alaska Native Population: 2010. Washington: U.S. Census Bureau. https://www.census.gov/history/pdf /c2010br-10.pdf.

O'Neill, Kate, Tyler Smith, and Ian Kennedy. 2022. "County Dependence on Monetary Sanctions: Implications for Women's Incarceration." RSF: The Russell Sage Foundation Journal of the Social Sciences 8(2): 157-72. DOI: https://doi.org/10 .7758/RSF.2022.8.2.08.

Olson, David E., and Gerard F. Ramker. 2001. “Crime Does Not Pay, But Criminals May: Factors Influencing the Imposition and Collection of Probation Fees." The Justice System Journal 22(1): 2946.

Page, Joshua, and Joe Soss. 2017. "Criminal Justice Predation and Neoliberal Governance." In Rethinking Neoliberalism: Resisting the Disciplinary Regime, edited by Sanford Schram and Marianna Pavlovskaya. New York: Routledge.

Park, K-Sue. 2018. “Insuring Conquest: U.S. Expansion and the Indian Depredation Claims System, 1796-1920." History of the Present 8(1): 57-87.

Pettit, Kathryn L.S., G. Thomas Kingsley, Jennifer Biess, Kassie Bertumen, Nancy Pindus, Chris Narducci, and Amos Budde. 2014. Continuity and Change: Demographic, Socioeconomic, and Housing Conditions of American Indians and Alaska Natives. Washington: U.S. Department of Housing and Urban Development.

Pommersheim, Frank. 1991. "Tribal-State Relations: Hope for the Future?" South Dakota Law Review 36(2): 239-76.

Pruitt, Lisa R, Amanda L. Kool, Lauren Sudeall Lucas, Michele Statz, Danielle M. Conway, and Hannah Haksgaard. 2018. “Legal Deserts: A Multi-State Perspective on Rural Access to Justice." Harvard Law and Policy Review 13: 15-156.

Rosay, Andre B. 2016. “Violence Against American Indian and Alaska Native Women and Men: 2010 Findings from the National Intimate Partner and Sexual Violence Survey." Washington, DC: National Institute of Justice.

Ruback, R. Barry, and Valerie Clark. 2011. “Economic Sanctions in Pennsylvania: Complex and Inconsistent." Duquesne Law Review 49(4): 751-72. 
Sanchez, Amairini, Michele Cadigan, Peyton Jacobsen, Dayo Abels-Sullivan, Sam Sueoka, and Bryan L. Sykes. 2022. “Punishing Immigrants: The Consequences of Monetary Sanctions in the Crimmigration System." RSF: The Russell Sage Foundation Journal of the Social Sciences 8(2): 76-97. DOI: https://doi.org/10.7758/RSF.2022 8.2.04.

Sparks, Tony. 2017. "Neutralizing Homelessness, 2015: Tent Cities and Ten Year Plans." Urban Geography 38(3): 348-56.

Steinman, Erich. 2012. “Settler Colonial Power and the American Indian Sovereignty Movement: Forms of Domination, Strategies of Transformation." American Journal of Sociology 117(4): 1073130.

_. 2016. “Decolonization Not Inclusion: Indigenous Resistance to American Settler Colonialism." Sociology of Race and Ethnicity 2(2): 21936.

Steinmetz, Kevin, Brian P. Schaefer, and Howard Henderson. 2017. “Wicked Overseers: American Policing and Colonialism." Sociology of Race and Ethnicity 3(1): 68-81.

Taylor, Amanda K., Julie K. Stein, and Stephanie A.E. Jolivette. 2011. “Big Sites, Small Sites, and Coastal Settlement Patterns in the San Juan Islands, Washington, USA." Journal of Island and Coastal Archaeology 6(2): 287-313.

Ulmer, Jeffrey T., and Mindy S. Bradley. 2018. “Punishment in Indian Country: Ironies of Federal Sentencing Jurisdiction Over Native
American Crime." Justice Quarterly 35(5): 75181.

. 2019. "Criminal Justice in Indian Country: A Theoretical and Empirical Agenda." Annual Review of Criminology 2(1): 337-57.

U.S. Census Bureau (Census Bureau). 2015. American Community Survey 5-Year Estimates, 20112015. Washington: U.S. Department of Commerce. Accessed August 17, 2021. https://www .census.gov/programs-surveys/acs/data /summary-file.2015.html.

Veracini, Lorenzo. 2010. Settler Colonialism: A Theoretical Overview. Houndmills, UK: Palgrave Macmillan.

Weaver, Hilary N. 2012. “Urban and Indigenous: The Challenges of Being a Native American in the City." Journal of Community Practice 20(4): 47088.

Wells, L. Edward, and David N. Falcone. 2008. "Tribal Policing on American Indian Reservations." Policing 31(4): 648-73.

Wilkins, David E., and K. Tsianina Lomawaima. 2001. Uneven Ground: American Indian Sovereignty and Federal Law. Norman: University of Oklahoma Press.

Wolfe, Patrick. 1999. Settler Colonialism and the Transformation of Anthropology: The Politics and Poetics of an Ethnographic Event. New York: Cassell.

Young, Thomas J. 1990. “Native American Crime and Criminal Justice Require Criminologists' Attention." Journal of Criminal Justice Education 1(1): 111-16. 